\title{
The Bay of Bengal: Next theatre for strategic power play in Asia
}

\section{Mohammad Humayun Kabir, Amamah Ahmad}

\section{Abstract}

This paper explores the factors behind the increasing strategic significance of the Bay of Bengal in the current geopolitical context.

The study starts by highlighting the factors contributing to the rising importance of the littoral region from a general economic, geopolitical and energy perspective. It then analyses the specific objectives and strategic aspirations of the major powers involved in the Bay, and how those may turn the area into a hub of converging, and/or conflicting interests. The focus is then shifted toward the smaller littoral nations and their individual relations with the major players. Finally, challenges to stability in the region are discussed, and a cooperative approach is suggested for the context of the Bay.

The paper argues that the strategic importance of the Bay will considerably increase in the coming years. As the nations involved are major and rising powers, the power play in the area will inevitably reshape the dynamics of the region. The interests that are at stake are also of crucial importance to the countries involved; hence, their protection will also demand a rapid militarization of the littoral. Most of these countries are now redirecting their focus from land to sea, which is adding a whole new dimension to the importance of the Bay. However, this paper argues that cooperation and competition is in all the nations' best interest, as any conflict in the Bay region could bring in political, economic and energy insecurity affecting all the concerned countries. Another dimension this paper explores is the implication of this competition on smaller nations and their role in the larger schemes of the major powers.

In order to lay out an exhaustive and holistic view, historical, economic, military, geopolitical and social factors have been taken into account in this research.

\section{KEY WORDS:}

Bay of Bengal, strategic competition, Indian Ocean region, militarization, regional integration, littoral nations. 


\section{Introduction}

During the Cold War era, strategic ocean theatres were mainly centred on the Atlantic and the Pacific. For a long time, the Indian Ocean had not been considered a forecourt for potential superpower competition, let alone confrontation. In recent years, however, the scenario has changed considerably. The unprecedented economic growth of China, doubling every seven years since Deng's reforms, the rise of India to the status of a major power in Asia through its increased trade and productivity, and the democratization and economic growth of developing nations drastically increasing energy demand, have completely recalibrated the importance of the Indian Ocean Region (IOR) to the world. In his book entitled "Monsoon" Robert D. Kaplan argues that the IOR is on its way to becoming the nexus of world power and conflict in the coming years (Kaplan 2010). As the Bay of Bengal (BoB) is a major part of the IOR, the power plays taking place therein will have a significant effect in shaping the regional strategic landscape as well.

In terms of significance, the region has been dynamic since the third century BCE approximately, long before the Europeans had discovered the IOR. Then, the trade routes connected East Asia, Southeast Asia, South Asia, Arabia and East Africa (Szczepanski 2014). For centuries, the trade routes led way to exchange of commodities and also of religious thoughts, allowing the spread of many religions and cultures across the continent and beyond. A turning point in the history of the IOR sea trades was the arrival of the Portuguese sailors under Vasco de Gama in the 15th century. During that time, trade from Asia to Europe was booming, as the demand for Asian luxury goods was very high. However, there was not much demand in Asia for European commodities. From that imbalance, the trade dynamics changed - the Portuguese decided to enter the IOR as pirates rather than traders, they began to seize port cities, rob and extort local merchants. This was followed by the arrival of the Dutch East India Company in the early 17th century. This European power adopted a more ruthless approach by seeking a monopoly over the lucrative products of the region. Around 1680, the British East India Company followed suit, which led to conflicts over the control of the Indian subcontinent's sea trade routes. This strong European presence 
in the region was later concretised through the colonisation era, which officially ended the practise of reciprocal trade, making the Asian trading empires grow weaker, poorer and eventually collapse (Szczepanski 2014).

Now, the region, which had been under strong Western influence and power, is slowly going back into the hands of the indigenous nations. In terms of partnerships, there is also a change in the actors involved while the past decades had been characterised by a strong North-South cooperation, now South-South cooperation is flooding the sub-regions.

The $B O B$ is becoming more and more strategically significant for many countries. With ever-increasing energy demands, the Sea lines of Communications (SLOC) and their protection are becoming a priority for the Asian countries. Since the BoB leads to the Malacca Strait, that opens up to the South China Sea (SCS), these routes are crucial to economies in the SCS (China, Japan) - which explains the growing interest and involvement of extra-littoral players in the Bay. Protection of SLOCs has added to the importance of increasing maritime power projection capabilities in the BoB. Even though relatively manageable in terms of confrontations between nations, the intentions of the major powers are increasingly being questioned. In terms of foreign policy strategy, China is clearly adopting a "Look South" policy, reflected through its heavy infrastructure investments in the countries around the Bay. India is opting for a "Look East" policy, to intensify connectivity to Southeast Asia and the US with its Asia "Rebalancing" strategy which shifts its focus from the Middle East to this dynamic region.

In addition to the major powers and their interests in the BoB, the littoral nations are also gaining in importance. Bangladesh has made commendable economic progress. The country is now inviting investment in maritime infrastructure building in the Bay to upgrade its strategic value. Another aspect of Bangladesh's policy that has had a positive impact on the Bay was the dispute resolutions through the International Tribunal for the Law of the Sea (ITLOS) with Myanmar in 2012 and, very recently, with India in July 2014. Myanmar just opened up its doors to foreign investment and is attracting a plethora of actors for its resource endowments. Having all these nations at play, following similar ambitions and objectives in the BoB, will inevitably lead to competition and maybe even conflict. 
As the sub-region is very dynamic and subject to changes, it is important to examine the competition that is taking place and explore the possible implications for the littoral and extra-regional powers. This paper will examine these aspects with a view to shedding some light on the current and future situation in this dynamic region.

The objectives of this paper are to (1) identify the factors contributing to the rising importance of the Bay of Bengal, (2) highlight the significance of increased naval focus therein, (3) analyse the strategic competition taking place between and among the littoral and extra-littoral actors in the Bay of Bengal, (4) examine the implications of this growing competition in the BoB for smaller littoral nations of the Bay and their roles in the strategies of major players, and (5) outline the emerging scenarios and incentives for greater peace and stability in the sub-region.

This paper argues that the Bay of Bengal's strategic significance will see a remarkable increase in the coming years. As the actors involved are Asia's major and rising powers, the need for energy security, increased connectivity and trade are going to be their main strategic objectives. Since the major powers are largely dependent on the SLOCs for their energy supply, the protection of those routes and competition over other resources have induced a rapid militarization of the region. As the current scenario involves many stakeholders and strategic interests, the risks of conflict are looming. However, we argue that the major players, due to their energy needs, common benefit of stability at sea for the SLOCs and connectivity for economic and strategic purposes, will gain more by cooperation and the use of soft power rather than through conflict. Additionally, it is suggested that smaller littoral nations play an important role in the larger strategic design of the major players. These countries are also benefiting from the dynamic competition in the BoB among bigger players and using it for their individual growth and development.

This paper is divided into five sections with an Introduction and a Conclusion. The first section provides a brief historical overview and some basic data on the Bay of Bengal. The second analyses the factors contributing to the rising importance of the region, mainly economic, political, energy and geographic dimensions. The main strategic objectives of the major players - India, China and the US - are discussed in the third section, with 
an attempt to explore the rivalries between the major powers and their conflicting interests converging in the Bay. The fourth section highlights the importance of the smaller littoral nations for the bigger powers, and looks at how the littorals can take advantage of the competition in the region and galvanize their own growth. Finally, the fifth section focuses on the challenges to stability and suggests a cooperative architecture for the BoB. The paper concludes by saying that cooperation is in every nation's best interest in this particular region and that a stable and competitive environment will achieve more than the use of hard power in the BoB waters and/or in its littoral nations.

\section{Knowing the Bay of Bengal}

\section{Location and Basic Data on the Bay}

Located in the northern extension of the Indian Ocean, the Bay of Bengal occupies an area of about 2,173,000 square km, making it the largest Bay in the world (Encyclopaedia Britannica 2009). It is situated between vital sea routes and stretches from Sri Lanka up to the coast of eastern India, curving under Bangladesh and Myanmar and heading south along Thailand and Malaysia until it reaches the northern coast of Sumatra in Indonesia (Yhome 2014). A quarter of the world's population resides in the countries bordering the $\mathrm{BoB}$, with approximately 400 million people living in its catchment areas; and these numbers are expected to increase by $20 \%$ by the year 2015 (Yhome 2014). This makes the Bay one of the most densely populated coastlines on Earth. Figure 1 shows a map of the Bay of Bengal and the littoral nations around it. 


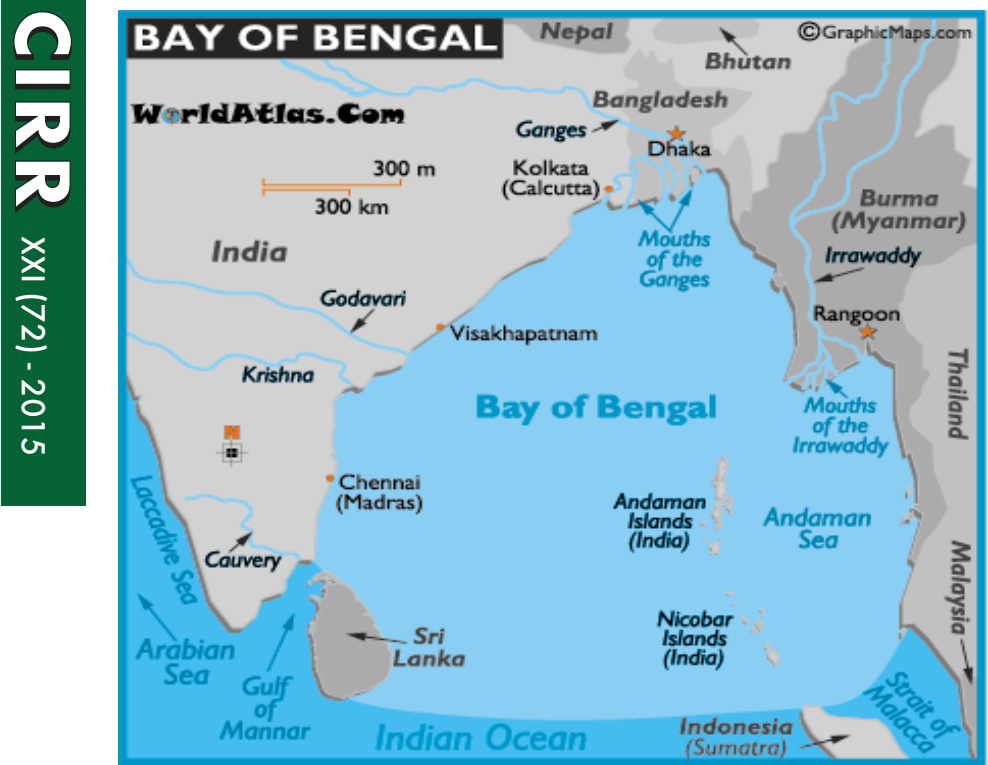

Figure 1: Map of the Bay of Bengal. Source: World Atlas Maps. Bay of Bengal

On a geo-strategic level, the BoB lies between two huge economic blocs - the South Asian Association for Regional Co-operation (SAARC) and the Association of South East Asian Nations (ASEAN) - connecting the South East Asian economy to Middle Eastern oil sources. According to the 2011 British Petroleum (BP) Statistical Review of World Energy, approximately 100 trillion cubic feet, or approximately $1 \%$ of the world's total unexploited oil and gas reserves are located along the coasts of Myanmar, India and Bangladesh (BP 2011). The tremendous economic potential that the Bay offers due to its untapped natural resources, makes it strategically central for its littorals, i.e. Bangladesh, Myanmar, Malaysia, Thailand, Singapore, Indonesia, Sri Lanka and India, as well as for global powers like the US and China.

\section{Historical Overview of the Bay}

Even before the Atlantic, the BoB served as a maritime highway between nations. For centuries, trade and human migration shaped the littoral and its surrounding states. In the period from 1600 to the 1800 s, the BoB witnessed an intensification of trade primarily by the Portuguese and the Dutch. By the 1820s, it was the British Empire that had a substantial grasp 
around the Bay's coasts (Amrith 2013: 64). Between the 1870s and the 1930s, more than 25 million people crossed the Bay, most of them being young men from southern and eastern India en route to the tea estates of Sri Lanka, the rubber plantations of Malaysia, and the docks and rice mills of Myanmar - although much of this migration was circular rather than permanent (Amrith 2013: 64). After the 1930s, however, environmental and politico-economic pressures started to erode this age-old configuration of interconnections.

Today, the Bay emerges as one of the most significant regions in the world due to its geological, economic, political and strategic characteristics. While the Bay still remains an arena for strategic competition between rising powers, as it was in the eighteenth century, today those powers are mostly regional rather than Western (Devare 2008).

\section{Factors of the rising importance of the Bay}

\section{Economic, Political, Energy and Connectivity Dimensions}

The rising importance of the Bay is closely linked to the rapid economic growth of its littoral nations and of the major powers involved in the Bay. If we look at China, the nation has become the principal importer of raw materials, is one of the biggest manufacturing nations globally, and is unquestionably the largest consumer market in the world. India and the smaller littoral countries have also increased exports and bilateral trade with South and Southeast Asian countries.

In addition to the economic factors, political changes facilitated growth and cooperation and brought more stability to the BoB littoral. Even though the majority of the littoral nations are considered to be weak or fragile states, there has been a visible process of democratisation. If we look at Myanmar, the country recently came out of half a century of military junta and is opening up to the world, economically and politically. Bangladesh is considered a weak state yet, despite unpropitious conditions, the country 
is making enormous and commendable economic and developmental strides. In that regard, the country was also identified as one of the N1 1 nations by Goldman Sachs (Goldman Sachs 2007).

Increased political and economic cooperation has allowed for the development of infrastructure projects in and around the Bay. For most of the Asian nations, this growth is accompanied by a rise in energy needs. China is expected to surpass the US in terms of energy demand by 2015. Figure 2, representing the countries that are among the highest net oil importers, shows China and India among the top 4.

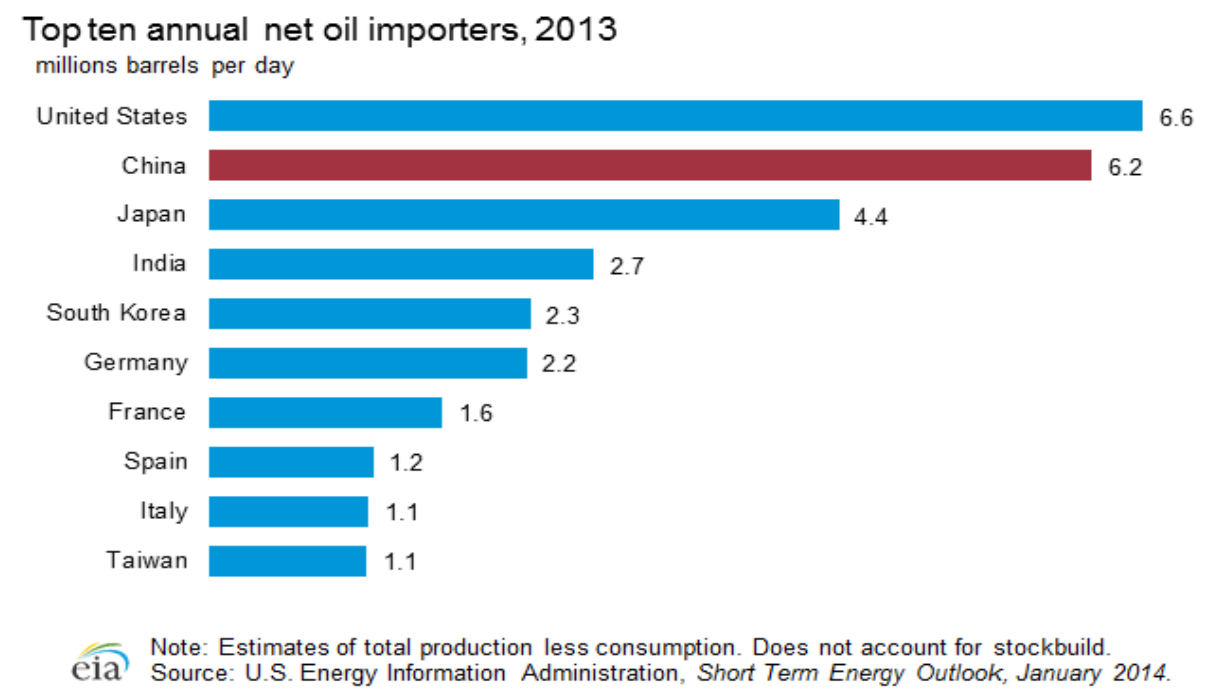

Figure 2: Top ten annual oil importers 2013.

China and India have now become heavily dependent on oil imports, which are expected to rise to $75 \%$ and $95 \%$ respectively of their total oil consumption by 2030 (shown in Figure 3 and 4). In terms of natural gas, their imports are also expected to increase to $40 \%$ (China) and 50\% (India) (HCSS 2010). This will cause the two countries to increase dependence on energy imports over land and by sea. As a result, the importance of the BoB as a transit region will keep increasing, as it will witness expansion of SLOCs and intensification of naval presence for both India and China. 


\section{China's oil production and consumption,1993-2015}

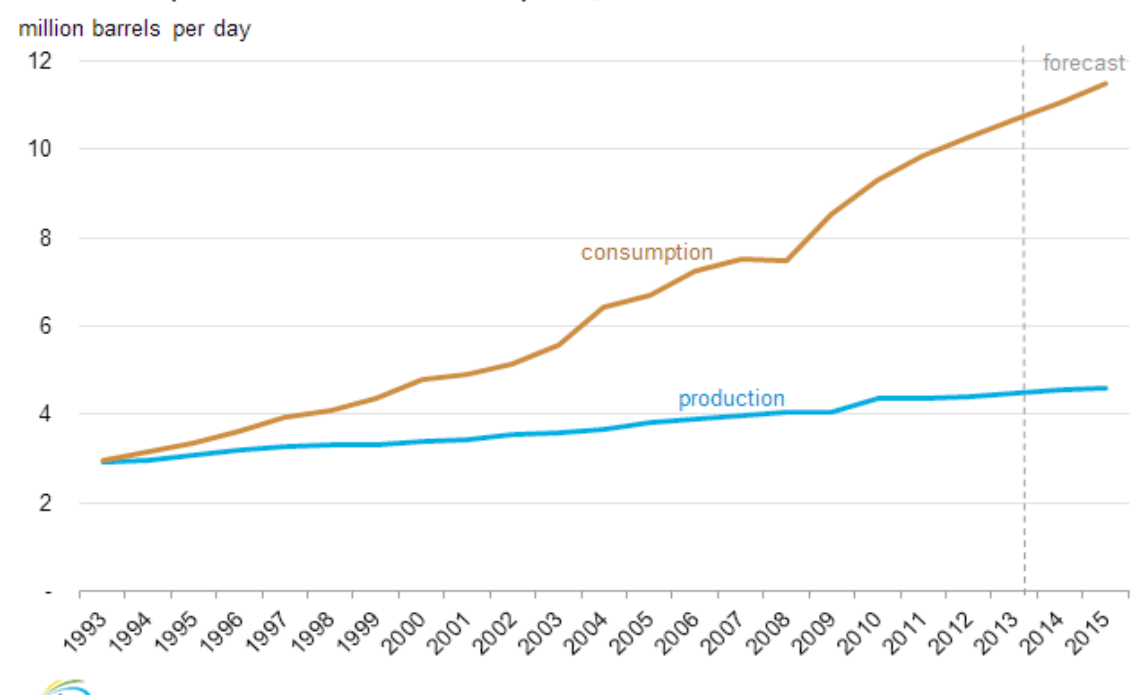

eia Source: EIA International Energy Statistics and Short-Term Energy Outlook, January 2014.

Figure 4: China's oil production and consumption, 1993-2015

Due to its strategic location, the BoB not only serves the littoral nations around the Bay but also other major actors like China and Japan, which through the Malacca Strait, access it for trade in goods and energy. Now, the major concern for many of these countries is to secure the SLOCs as trade and energy imports are crucial to their economies. This, in turn, has added a security dimension to the Bay-countries are now seeking to increase their maritime power and power projection capabilities.

In addition to securing the SLOCs, countries like Bangladesh are also putting an emphasis on delimitating their maritime boundaries to demarcate and secure blocks of natural resources for instance. The recent BangladeshMyanmar and Bangladesh-India maritime boundary dispute in the BoB, mostly motivated by exploration needs of natural resources or on a larger scale by the need to delimitate the territorial sea, the exclusive economic zone or the continental shelf, are a case in point of this renewed focus. It would be interesting to point out here that in the BoB, the stabilizing factor in these processes has been the trend of settling disputes in a diplomatic and rather cooperative manner unlike in the SCS, where 
tensions between China and the SCS littorals keep arising. Instead of using a bilateral mechanism, countries like Bangladesh opted for the assistance of International legal forums for their dispute resolutions. In the case of Bangladesh and Myanmar, following the events of November 2008, when the Myanmarese Navy led Korean exploration ships to Bangladeshi waters, Bangladesh took the issue to the ITLOS to avoid the occurrence of similar incidents in the future. The court gave its verdict in 2012, resolving the dispute. India and Bangladesh also recently settled the 40 year old maritime boundary dispute. Both countries had been engaged in long and inconclusive negotiations on the delimitation of their maritime boundary since 1974, engaging in eight rounds of bilateral negotiations. In October 2009 Bangladesh served India with notice of arbitration on the issue (Burke 2014). The case was handled by the Arbitral Tribunal in The Hague, and the court delivered its ruling in July 2014.

These disputes drew attention to the Bay, and the international community commended the manner in which they were resolved. Hence, despite instability in some of the littoral states, the overall mechanism for dispute resolution has been stable and territorial disputes were resolved peacefully. This in turn has built more investor confidence in and around the Bay for local and global actors mainly in the energy sector. Both nations are cooperating in order to individually and regionally benefit from the economic value of the $\mathrm{BOB}$, which could not be realised until and unless the dispute was settled (Keck 2014).

Another aspect that significantly adds to the Bay's importance is the growing demand of landlocked areas for access to the waters such as India's northeast, China's southern region, Nepal, and Bhutan. Having access to the Bay could have an enormous impact on their development and economic growth, as it is a major transit route for inter-continental and regional trade in commercial goods and natural resources.

These politico-economic factors have largely contributed to turning the BoB into the next geopolitical and geo-strategic hub of Asia. Increasing energy demand and strong militarization of the waters will inevitably spur competition among the major powers. Their strategies will determine if these interactions will be characterised by conflict, competition or cooperation. 


\section{Strategic competition in the Bay between regional and extra regional actors}

As this paper analyses the strategic ambitions of major players in the BoB, it is necessary to include their goals in the IOR as a whole. To a certain degree, their strategy in the BoB can be an extension of their strategy in the IOR in general. Geographically, the BoB gives access to other major sea lines, most importantly the Malacca Strait, hence it is important to acknowledge the indirect influences of the larger landscape. Kaplan (2010) warns that the region will become a centre of global conflict due to the intensification of trade through its routes but, more importantly, due to the fact that the interests of major players intersect and overlap in the area.

In the following sub-sections we will elaborate on the causes of increased competition between regional and extra-regional powers in the BoB. These are mainly defined by geostrategic (energy security, maritime power projection capabilities and connectivity) and economic (increasing significance of seaborne trade) factors.

On the one hand, there has been a considerable increase of energy demand by growing economies which has created energy security challenges in the region - the economies of the littoral and the hinterland nations of the BoB are generally resource-poor and hence tradedependent. On the other hand, the regional production has been declining, creating increasing reliance of these nations on foreign energy imports, which are mostly delivered by sea (Khan 2013).

Maritime presence and growth is another crucial element shaping the dynamics and forming the new configurations in the Bay. The recent maritime zone claims and boundary disputes among littoral nations are motivated by the emerging interests and the need for building adequate military capabilities to protect those boundaries and resources. Figure 5 represents the number and kind of military bases present in the IOR. 


\section{\begin{tabular}{l|l} 
COUNTRY LOCATION &
\end{tabular} \\ DETAILED FACILITIES}

\begin{tabular}{|c|c|c|}
\hline \multirow[t]{4}{*}{$\begin{array}{l}\text { UNITED } \\
\text { STATES }\end{array}$} & $\begin{array}{l}\text { Diego Garcia } \\
\text { (British IO Territory) }\end{array}$ & $\begin{array}{l}\text { Naval base, submarine base, support facilities } \\
\text { space surveillance network, NASA Space } \\
\text { Shuttle landing site, possible US nuclear weap- } \\
\text { on hub }\end{array}$ \\
\hline & $\begin{array}{l}\text { Changi Naval Base, } \\
\text { (Singapore] }\end{array}$ & $\begin{array}{l}\text { Maintenance, logistic support facility and train- } \\
\text { ing refueling, repair facilities }\end{array}$ \\
\hline & Kochi [India] & Base of mobile ship repair unit \\
\hline & Manama [Bahrain] & $\begin{array}{l}\text { HQ fleet, naval base, mine counter-measures, } \\
\text { facilities \& medical, munition, fuel mobility. } \\
\text { support facilities, airbase }\end{array}$ \\
\hline \multirow[t]{14}{*}{ INDIA } & Kochi & $\begin{array}{l}\text { Monitoring station, naval base, repair dry dock, } \\
\text { naval aircraft yard, refueling station }\end{array}$ \\
\hline & Goa & $\begin{array}{l}\text { Naval base, repair dry dockyard, refit and mod- } \\
\text { ernization of ships and submarines }\end{array}$ \\
\hline & Karwar & Naval base \\
\hline & Visakhapatnam & Submarines HQ, naval hospital \\
\hline & Mumbai & $\begin{array}{l}\text { Monitoring station, naval base, missile boat } \mathrm{HQ} \text {, } \\
\text { submarine base, naval hospital }\end{array}$ \\
\hline & Rambilli Mandal & - \\
\hline & Lakshadweep Islands & Patrol craft base \\
\hline & $\begin{array}{l}\text { Port Blair } \\
\text { [N\&A Islands] }\end{array}$ & Advance base, support facility, naval hospital \\
\hline & Maldives & - \\
\hline & $\begin{array}{l}\text { Jaffna Peninsula } \\
\text { (Sri Lanka) }\end{array}$ & - \\
\hline & $\begin{array}{l}\text { Trencomalee } \\
\text { (Sri Lanka) }\end{array}$ & Container port \\
\hline & $\begin{array}{l}\text { Madagascar } \\
\text { [Northern tip] }\end{array}$ & Monitoring station \\
\hline & Mauritius & Monitoring station \\
\hline & Seychelles & Monitoring station \\
\hline \multirow[t]{3}{*}{ CHINA } & $\begin{array}{l}\text { Marao Island } \\
\text { [Maldives] }\end{array}$ & Monitoring station \\
\hline & Seychelles & - \\
\hline & $\begin{array}{l}\text { Great Coco Island } \\
\text { [Myanmar] }\end{array}$ & Monitoring station \\
\hline
\end{tabular}

Figure 5: Military bases in the IOR. Source: HCSS report

In terms of geopolitical competition, there are three major powers at play in the BoB - India, China and the US. India considers the BoB as "home" 
and its strategy is mainly to adapt to other major players' interests in the region. China, though not a littoral country, is trying to increase its presence through growing cooperation with other littoral nations. The US, not a littoral nation either, is slowly shifting its strategic focus from the Middle East to Asia. In addition to these super/major powers, there are other countries that need to be taken into the equation such as Japan, Russia and the littoral states Bangladesh, Myanmar and Sri Lanka.

\section{China in the Bay of Bengal}

In order to understand the complexity of China's strategic situation, one needs to take into account its remarkable economic growth over the last decades. In just over a single decade, China's foreign trade went from $\$ 289$ billion dollars to an astounding $\$ 2.560$ trillion in 2005 (Eshel 2011 ). However, one main commodity that Beijing lacks is oil. Today, the country is the second largest global oil consumer. In order to sustain its economic growth, China's strategic priorities are to find reliable oil supplies and secure unencumbered SLOCs. These expanding economic and strategic interests may cause the PLAN to operate out of area in order to safeguard investments and SLOCs. This explains China's focus on military facilities along the SLOCs from China to the Persian Gulf (Eshel 2011). Figure 6 gives us a better idea of China's presence in the littoral nations. 


\begin{tabular}{|c|c|c|c|c|c|c|}
\hline COUNTRY & LOCATION & STATUS & USE & $\begin{array}{l}\text { MILITARY } \\
\text { FACILITIES* }\end{array}$ & $\begin{array}{l}\text { DETAILED } \\
\text { FACILITIES }\end{array}$ & $\begin{array}{l}\text { TYPES OF } \\
\text { SHIPS }\end{array}$ \\
\hline PAKISTAN & Gwadar & Operational & $\begin{array}{l}\text { Mostly } \\
\text { civilian but } \\
\text { also } \\
\text { military }\end{array}$ & $A, B, C, D$ & $\begin{array}{l}\text { Deep water port, } \\
\text { Signals } \\
\text { Intelligence } \\
\text { (SIGINT) facility }\end{array}$ & $\begin{array}{l}\text { No data } \\
\text { available }\end{array}$ \\
\hline BANGLADESH & Chittagong & Operational. & $\begin{array}{l}\text { Military/ } \\
\text { civilian }\end{array}$ & $B, D, C$ & $\begin{array}{l}\text { Container port, } \\
\text { langest navy base, } \\
\text { logistics } \\
\text { bunkering } \\
\text { facilities }\end{array}$ & $\begin{array}{l}\text { Small and } \\
\text { medium } \\
\text { warships }\end{array}$ \\
\hline \multirow[t]{4}{*}{ MYANMAR } & $\begin{array}{l}\text { Ramree } \\
\text { Island } \\
\text { [kyaukpyu] }\end{array}$ & Operational & Military & $A, B, C, D$ & $\begin{array}{l}\text { Naval base, } \\
\text { monitoring } \\
\text { station, refueling } \\
\text { station }\end{array}$ & $\begin{array}{l}\text { No data } \\
\text { available }\end{array}$ \\
\hline & $\begin{array}{l}\text { Hainggyi } \\
\text { Island }\end{array}$ & Operational & Military & $A, B$ & $\begin{array}{l}\text { Naval base, } \\
\text { monitoring } \\
\text { station }\end{array}$ & $\begin{array}{l}\text { No data } \\
\text { available }\end{array}$ \\
\hline & Thilawa & Operational. & $\begin{array}{l}\text { Civilian/ } \\
\text { military } \\
\text { capabilities }\end{array}$ & $A, D$ & $\begin{array}{l}\text { Monitoring } \\
\text { station, shipyard }\end{array}$ & $\begin{array}{l}\text { Ships } \\
\rightarrow 10.000 \text { ton } \\
\text { deadweight } \\
\text { (Myanmar } \\
\text { has only few) }\end{array}$ \\
\hline & $\begin{array}{l}\text { Zadetkyi } \\
\text { Kyun Island }\end{array}$ & Operational. & Military & A, B & $\begin{array}{l}\text { Naval } \\
\text { base,maritime } \\
\text { surveillance radar }\end{array}$ & \\
\hline SRI LANKA & Hambantota & Expected & $\begin{array}{l}\text { Civilian/ } \\
\text { military } \\
\text { capabilities }\end{array}$ & $B, C, D$ & - & $\begin{array}{l}\text { Military } \\
\text { vessels, } \\
\text { possibly } \\
\text { nuclear } \\
\text { submarines }\end{array}$ \\
\hline
\end{tabular}

Figure 6: China's investments abroad. Source: HCSS Report

As other powers shift their focus, Beijing is also focusing on its "Look South" approach. In 2013, President Xi Jinping suggested two initiatives, the Continental Silk Route and the Maritime Silk Route. The initiatives would extend China's influence in two belts: The Bangladesh-China-IndiaMyanmar Forum for Regional Cooperation (BCIM), which would also connect China's Yunnan province to the BoB and the China-Pakistan Silk Road Economic Belt, which is a railway project that would connect China's Kashgar to the Gwadar port in Pakistan (Jia 2014). These initiatives would fulfil the purpose of greater connectivity in the region for Beijing.

In addition to Beijing's quest for energy and connectivity, this orientation has been also triggered by China's uneasiness of the US "Rebalancing" 
strategy. In response, China has continued its naval build-up which has seen an exorbitant 500\% rise since 2000 (Jha 2014).

Consequently, current Chinese maritime policies are intended as a warning, especially to the US, not to intervene in Chinese affairs, especially in the South China Sea (SCS). Parallels can be made here to the US Monroe doctrine, declared in 1823 to deter European powers from meddling in seas the US considered as its natural sphere of influence (Yoon 2014).

Interestingly, China is playing two different games in two different seas. In the SCS, where China is a littoral nation, there is a strategic competition with the US and rival Asian nations - China is allegedly defying the international law of the sea by continuing to patrol and police near ASEAN countries (CNAS 2009). This tense geo-strategic area is China's foreign policy priority, as conflicts here are mainly related to its territorial sovereignty.

Very recently, president Xi Jinping officially declared China's intention to strengthen its frontier defences on land and sea. He also called for the country to boost its military into a force that can "win battles" (Daily Star 2014). As a result, the People's Republic of China has adopted a strategic approach that includes land, maritime, economic and energy security components (Rajan 2014). The naval build-up has added a new dimension to the PLAN's capabilities- going from that of conducting coastal defence activities to the potential of high sea defence.

For a long time, China had given primacy to land security. In the 1980s when China began opening up, new economic linkages were complemented by greater dependence on sea lanes for export and import of goods and oil respectively (Bedford 2009). Additionally, with the fall of the Soviet Union, China could stop focusing on its land border and turn its attention toward the sea.

Securing SLOCs has become one of its main objectives and a way to address the "Malacca Dilemma" and reduce its reliance on the Malacca strait through which about $80 \%$ of its energy import is transported. This makes Beijing's energy security vulnerable because of the US' objective to control the Strait and because of pirate attacks. China is therefore exploring other options, which would allow it to bypass the Strait, by 
transporting resources through roads and sea from the BoB (Stratrisk 2013). The Chinese-built gas pipeline from Kyaukpyu in Myanmar to Kunming, which became operational in 2013, with a parallel crude oil pipeline, is one such project (Samaranayake 2014).

Additionally, China is seeking port access agreements with littoral countries of the Bay. However, as India is also extending its sphere of influence east and west on land and at sea, there is a possibility that it will 'bump heads' with China which is protecting its interests and is expanding its reach in the region.

Finally, be it energy needs or strategic motivations, China's commercial and infrastructure investment in the region have been astonishing. It has offered the BoB nations billions of dollars in loans for the construction of ports and roads and for other infrastructure projects, ensuring its influence in and around the Bay (Samaranayake 2014). For instance, Beijing has been deeply involved in countries like Sri Lanka, where it has contributed approximately $\$ 4$ billion in loans, grants and aid since the end of the civil war in 2009 and is responsible for almost $70 \%$ of the country's infrastructure projects (Columbage 2014). Currently, China and Bangladesh are also in talks over the $\$ 9.03$ billion worth of financial support that the latter requested from Beijing (mostly for infrastructure development projects over a period of five years) (Kabir 2014). On the regional scale, in November 2014, China offered $\$ 20$ billion in preferential and special loans to develop infrastructure and increase cooperation with its South East Asian neighbours (Shannon 2014). All these examples reflect the Asian Giant's stronghold over the sub regions.

\section{The US in the Bay of Bengal}

In recent years, US interests in the region have grown and evolved because it recognizes the tremendous potential this sub-region has due to its demographic strength, the transiting of high value goods, and its resource endowments (Kapur 2014). In addition, some scholars argue that America's shift in focus may also have been triggered by China's fast expansion in the region. As a result, the US is now reallocating resources in Asia as its Rebalancing Strategy. 
As was expected, the deployment of US ships and personnel in Asia and its increasing cooperation with the ASEAN states generated a wave of criticism from China. The Obama administration renamed the 'Asia Pivot' as the 'Rebalancing' strategy, as China was showing discontent with containment strategies aimed at preventing its rise. The new "Rebalancing" strategy now officially aims at engaging China, strengthening ties with allies and creating new strategic partnerships. The underlying security challenges that arise from this scenario lie in the fact that the US, its allies and strategic partners all see an attractive economic partner in China. This in turn creates doubts for the US of having its allies stand by their expected commitments in their differences with China (Chintamani 2014).

Another important factor is that the US does not have the same presence in the BoB as it does in the SCS, where it benefits from greater and longer partnerships with the ASEAN nations. To add to its disadvantage, most of the countries of the Bay already have strong ties with either India or China. Hence, the current US strategy tries to play on these dependencies by working closely with South Asian nations in order to prevent them from becoming overly reliant on either of the two major powers.

In terms of military strategy, the US Navy has unparalleled power projection capabilities in South and Southeast Asian waters. China's renewed assertiveness in the SCS and its growing interest in the BOB is of particular concern to the US which sees China's rise as a threat to its role as a provider of regional stability.

In sum, after having neglected the sub-region for many years, the US is challenged by the growing influence of India and China as major maritime and economic powers in the area, for the first time threatening its hegemony.

In order to set limits on China's expansion, the principal task of the US Navy would be to covertly leverage the sea power of India, in the IOR, and Japan, in the Western Pacific. It is in the US' long-term economic interest to prevent the region from being dominated by any single state thereby disturbing the balance of power in the region. Accordingly, one of its crucial aims is to balance the growing levels of Chinese investments in the regional countries. 
Moreover, the prospect of any key choke points being controlled by any Asian nation could tilt the balance of trade further toward Asia. The persistent concerns of piracy attacks in the Strait of Malacca demonstrate the consequences of failing to ensure free and secure access through the choke point. Nevertheless, the dilemma for the US is that by preventing or blocking supply to China and India, it risks stifling the world economy-and so is naturally averse to pursuing this option. Additionally, with regard to a US-Chinese understanding at sea - crucial for the stabilization of world politics in the current geopolitical landscape - the US is trying to seize opportunities to incorporate China's Navy into international alliances.

Yet, to achieve its geopolitical objectives in the region, the US capitalizes on the India-China rivalry to its own advantage. It engages with India within its strategy of inclosing China, and encourages India to strengthen relations with Southeast and Central Asian states. The fact that the US is enhancing its naval presence in the Bay of Bengal indicates the region's growing central position in current world political affairs (Stratrisk 2014).

\section{India and the Bay of Bengal}

As part of the greater IOR, the BoB has historically been regarded as India's sphere of influence. However, until recently it was treated as backwaters, and it was only after external actors started showing interest in the region that India realized the importance of protecting this geo-strategic area situated right above one of the world's busiest SLOCs.

In terms of its foreign policy and strategy, India has adopted a 'look East' approach. The nation is also showing interest in building what it calls the "Bay of Bengal community", where it envisages greater security cooperation amongst the littoral nations. As a result, India may focus on strengthening security ties with countries like Bangladesh and Myanmar. In other frameworks, such as the BCIM, the three countries and China are collectively cooperating. However, this time, India may opt for cooperation that does not include China as a reaction to China's assertiveness in the BoB region.

The significance of the BoB to India's economy is immense. In 2013, $95 \%$ of India's foreign trade by volume and $75 \%$ by value were conducted by 
sea; and more than $75 \%$ of its oil was imported by sea (Hughes 2014). With India's economic growth, the importance of its Navy also grew. As part of its maritime strategy, India states explicitly that it will strive to ensure the safety of the Ocean's SLOCs as being critical for economic growth, for itself and for the global community.

It is also cognizant of the fact that smaller nations in its neighbourhood, as well as nations that depend on the waters of the BoB for their trade and energy supplies, have come to expect that the Indian Navy will ensure stability and tranquillity in the waters around its shores (HCSS 2010).

Between 1980 and 2009, the Indian Navy progressed from being a "brown-water" to almost a "blue-water" force. The country's economic rise fuelled its defence budget and strengthened its position in the IOR. The Navy is also involved in other activities such as providing critical training and equipment to numerous Indian Ocean countries, and its MILAN exercise now includes sixteen Asian and African navies and coast guards (Samaranayake 2014).

Furthermore, Prime Minister Modi asserted that he had accorded the highest priority to the modernization of defence forces, as strong security was necessary for an atmosphere of peace, amity and harmony in the country. Consequently, India's new maritime doctrine includes new policies such as Counter-Terrorism and Anti-Piracy missions. Since the country cannot match China's force-for-force, it needs to seek bilateral alliances, maritime domain awareness, and network-centric operations. In that regard, enhancing the security of small island states is an integral part of that strategy (Vines 2012).

An additional reason behind strengthening its naval power is India's "Hormuz dilemma"; it refers to its dependence on imports through the Strait, close to the shores of Pakistan, where the Chinese are helping the Pakistanis develop deep-water ports. India's objectives are hence to gain "strategic autonomy". This policy is aligned with the Indian goal of achieving superpower status and it is in this context that we see India opposing the presence of extra-regional powers in the BOB and the IOR in general (Stratrisk 2014). 
Delhi's naval modernization may also be the outcome of a perceived maritime threat posed by China's naval growth. In reaction, India is simultaneously developing relationships with states in Southeast Asia and the Western Pacific, causing some in China to question its motives. There is fear in Delhi that Beijing may be outrunning them and strengthening its strategic position in the Bay. China's investment in infrastructure and financial aid to the littoral countries could pose a serious threat to India which, up until now, remained the most important partner for many of these nations. Now, Delhi is re-focusing on the Bay of Bengal Initiative through a Multi-Sectoral Technical and Economic Cooperation (BIMSTEC), with emphasis on improving transport connectivity across the southern Asian littoral. It is also sponsoring the construction of new road and river connections between its land-locked northeast states and the BoB through new port facilities at Sittwe in Myanmar, to be completed by 2015.

Additionally, Indian officials have welcomed the US rebalance to Asia but made it clear that its "Look East Policy" is separate from the US rebalance and driven by Indian and not US interests, thus the interests are not synonymous. Nonetheless, a number of counter-terrorism and anti-piracy efforts have been conducted in coordination with American forces. US interest in countering the threat of terrorism in South Asia has pushed India and the United States towards more substantive military cooperation.

India's economic and political links across the BoB are growing, accompanied by an expansion of India's regional security role. The nation has long aspired to be recognized as the predominant power in the BoB and to assume a greater strategic role in Southeast Asia. These ambitions are consistent with the perspectives of many ASEAN states which generally perceive India as a positive factor in the regional balance of power, in contrast with China (Brewster 2014).

\section{Sino-Indian Rivalry in the Bay}

Historical mistrust between China and India has encouraged mutual suspicion regarding each other's intentions. India and China both view the BoB as a crucial frontier in their competition over energy resources, shipping lanes, and cultural influence. The competition stemming from the two countries expanding their regional sphere of influence in each other's backyards may result in skirmishes over energy, SLOCs or maritime issues. 
Up until now, the strongest manifestation of Sino-Indian rivalry in the BoB was in Myanmar where they both connect through Myanmar to their economically weaker regions, namely India's Northeast and China's Yunnan province. However, since 2011 Myanmar opened its economy to the Western world after the US and Europe lifted sanctions (BBC 2014), creating more partnership options as the reforms attracted a wave of foreign investors. This in turn reduced Sino-Indian competition by making space for new actors and creating more balance in the previously polarized scenario.

Another major aspect of the rivalry lies in the so-called String of Pearls Strategy that China allegedly pursues. However, although there is competition, there is little evidence that the Chinese are planning an encirclement of India with their naval facilities stretching from southern China across the Indian Ocean. Their strategy appears benign, seeking agreements, allowing access to facilities for resupply, etc. The Chinese are here not for bases but for access. Bases would involve huge amounts of investment and would have political implications. It is not just the Chinese Navy that seeks access, the Indian Navy pursues access facilities too but follows a different strategy from that of the Chinese. While the Chinese provide aid in infrastructure building, the Indians create small pockets of bilateral naval exercises (Agnihotri 2014).

In an attempt to reduce suspicion, China has recently invited India to join the country's efforts of building a wide network of new silk roads on land and sea with the aim of increasing global connectivity (Time of India 2014). Another challenge for China may be India's military reaction making Chinese sea lines more vulnerable; Beijing is already worried about the Malacca dilemma, and now the Andaman and Nicobar (A\&N) Command will put India's naval and air power in a position to control access to the Strait of Malacca (McDevitt 2013). Whether it is the US or India, whoever controls the Strait, will have a stronghold on Beijing's energy access, which constitutes a serious concern for China. 

the Bob

The littoral surrounding the $B O B$ is arguably one of the most complex regions in the world, comprising of a diverse range of economic, political and social cultures that has created a mix of idiosyncratic opportunities and risks in each state. The relations that these nations maintain with each other affect their development - or lack thereof - at a time when interdependencies are increasing in the region and beyond (Cordesman \& Toukan 2014). Much like Central Asia, a multi-vector "Great Game" in the South Asian region includes numerous processes such as the US' rebalancing, China's assertiveness, Russia's re-entry as a global power, Japan's quest for economic revival, India's Look East policy, politics of energy security, and so on. With the evolution and intensification of these processes, the regional security in the BoB and the socioeconomic conditions are being profoundly transformed.

\section{The Role of Littoral Nations in the Strategies of Major Powers and the Implication of Strategic Competition on Littoral Nations}

As the U.S., China and India adopt a macro approach, littoral nations seek ways to pursue their own development, essentially through infrastructure development, decreasing small nation dependencies, and creating new partnerships. Additionally, the existence of a competitive environment is a determining factor in promoting regional integration. As we can see for the littoral nations, beside the three major powers involved in the Bay, other nations like Japan and Russia are also taking advantage of this competition to make their way into the BoB through the littorals.

Bangladesh and Myanmar are crucial entry points to non-littoral states in the BoB such as India's Seven Sisters, China, and Japan. These countries need the Bay for their internal development, their connectivity to the rest of the region and for strategic purposes. In this regard, Bangladesh and Myanmar are headed to become bridges between South and Southeast Asia. These new strategic opportunities are pushing these nations to modernize their infrastructure, increase connectivity and bank on their 
strategic geographic location.

Following are some of the important investment and strategic partnerships that reflect the nature of the relationships between the littorals and the major powers in the BoB region.

\section{The Importance of Sri Lanka}

Delhi and Colombo enjoy a strong trade and investment relationship; the latter is India's largest trading partner in South Asia and India is Sri Lanka's largest trading partner globally. In addition, Colombo is one of the largest recipients of development credit by the Indian Government, which mostly comes in the form of disaster-relief and infrastructure building.

The two neighbours are also enhancing their defence relationship through extensive training (Government of India 2014).

Sri Lanka also shares robust ties with China; the latter is its largest source of Foreign Direct Investment (FDI). China has also provided development loans for projects such as the new Colombo Port Terminal, Hambantota Port, and a four-lane expressway among others. These investments have played a pivotal role in accelerating Sri Lanka's development in the region. In return, the country recently agreed to join China's ambitious Maritime Silk Route project, which reflects a strategic partnership both will benefit from. For China, access to Hambantota is essential for its new strategic, connectivity and economic aspirations; for Sri Lanka, this can be an opportunity to become an important player in the development of BoB trading ports (Goodman 2014).

Sri Lanka is a willing and capable partner in effectively combating violent extremism, trafficking and piracy, thereby helping to ensure the maritime security of the region. In this regard the US' anti-extremism approach has opened up avenues for cooperation. As both China and India will continue to engage extensively with Colombo, Washington has interest in having closer security ties, as in the other littoral nations. 


\section{ก The Importance Of Myanmar}

If we look at Myanmar, the new government has been approving projects that had been sitting idle for years (Economist 2014). This dynamic regional context has allowed Nay Pyi Taw to deal with a plethora of new partners competing to enter its resource-rich market. The country has been leapfrogging since its recent reforms and experiencing unprecedented FDI growth since 2009.

For India, Myanmar is of great strategic importance - the country can become India's link to Southeast Asia as it is a part of ASEAN, vital for India's "Look East" policy. Many Indian companies have largely invested in trade and infrastructure, for example the Kaladan project which would connect the Kolkata Port to Sittwe Port. Another project that would improve India's connectivity is the upgrading of the Kalewa-Yargyi road to a highway (Ramaswamy \& Maini 2014).

Nay Pyi Taw holds great strategic importance for China due to its energy endowments. The pipelines through Myanmar have the potential to help China reduce its heavy dependence on the Strait of Malacca for the transportation of energy. This, of course, has strategic implications against the backdrop of the United States' rebalancing in Asia and the on-going maritime disputes in the SCS. The successful building of the pipelines through Myanmar could reduce China's dependence on the Strait of Malacca by $30 \%$ (Melkulangara 2013).

Japan is similarly showing interest in Myanmar. During a recent visit, the Japanese Premier agreed to cancel the $\$ 1.74$ billion debt owed by the country to Japan, but also pledged to lend Myanmar more than half a billion dollars for infrastructure and power projects in the country (Song 2013). Japan is also developing the Thilawa Special Economic Zone in Thanhlyn-Kyauktan area of suburban Yangon. The multi-million project includes building a seaport, roads and other infrastructural development programmes (Asia News Network 2013).

In terms of security, both India and China have been strengthening their military cooperation with Myanmar. Over the years, Myanmar has gotten military equipment supplies from China and received training for 
officers from both India and China. The country is trying to balance its dependence on China by exploring its other strategic partnership options (Yhome 2014).

Russia is another player asserting its presence in Myanmar. Russian Foreign Minister Sergey Lavrov, in his visit to Myanmar, called for the complete dismantling of sanctions against the country. It would not be surprising to see Russia making offers to build a nuclear power plant in Myanmar or engaging in weapons trade (Melkulangara 2013).

\section{The Importance of Bangladesh}

For India, Bangladesh's significance for the access to its Seven Sister's cannot be underestimated. Access through the country can be a key to the development of the Northeast of India as it could access the sea to connect to larger markets for its products.

Economically, both countries share a strong and significant trade relationship despite a considerable trade deficit in favour of India. India has also provided the country with lines of credit for large infrastructure projects. However, the arrival of China as a competing power in the region has also given Bangladesh some leeway and has had a balancing effect in terms of the country's protracted dependency on India.

As for China, the same strategy it uses in Sri Lanka applies to Bangladesh. Strategically, access to ports in Bangladesh can facilitate Beijing's oversight of its SLOCs and be a key geographical location for its envisaged Maritime Silk Route. For the past four decades, China's contribution to Bangladesh's development in the form of economic aid, military assistance and infrastructure development has been significant. More recently the emphasis is being put on infrastructural development, which is largely benefiting Bangladesh and China for strategic purposes such as greater connectivity to China's Yunnan province.

Like China, Japan has also been trying to make its way into the BoB through Bangladesh. Economically and strategically, Japan has been increasing its influence in the littoral nations and showing greater interest in the region. Tokyo's new strategy may have been adopted due to the 
country's economic issues and the security environment in East Asia (the China factor), making the nation turn toward South Asia (Bangladesh and Myanmar). This move could also allow Japan to find alternative markets for goods and investment and alternative locations for production.

Among other projects, the Bay of Bengal Industrial Growth Belt (BIG-B) plan is a strategic initiative proposed by the Japanese Prime Minister, Shinzo Abe, which aims to promote industrial agglomeration along the DhakaChittagong-Cox's Bazaar belt, and enhance economic ties stretching from the Pacific to the Indian Ocean (Daily Star 2014). The initiative would comprise three pillars. The first pillar is industry and trade; this would mainly consist of constructing the long-awaited deep-sea port on Matarbari Island, which would offer Bangladesh an important trade gateway to the rest of Asia and beyond. The second pillar is energy, the Matarbari Island has the potential to be developed into a massive supply base of primary energy such as coal, LNG, and oil. The electricity harnessed from those sources could catalyse development in industry and trade. The final pillar is transportation, which would enable greater industry, trade and energy production between Japan and Bangladesh. The initiative, approved in August 2014, will also allow Bangladesh to provide a gateway to the BoB, boost regional economics, and play a central role in strengthening the nexus between Southeast Asia and South Asia (Bhatnagar 2013).

The US and Bangladesh established a bilateral security dialogue in April 2012, through which the US is providing assistance to the Bangladesh Navy in counterterrorism and maritime interdictions. This US-Bangladesh bilateral defence relationship is currently one of the most robust in South Asia.

Moscow is set to be a strong competitor to Washington in its aspiration of getting a foothold on Bangladesh's energy reserves. The focus of the recent visit of Prime Minister Sheikh Hasina to Moscow (which was the first visit by a Bangladeshi Prime Minister in 40 years) was on energy and arms purchase. Russia is investing heavily to finance its arms exports, as well as to build the first nuclear reactor in Bangladesh (Bhadrakumar 2013).

China is arguably exerting the most influence on the littoral nations. The strategy of "China finances and builds transportation routes leading to its 
hinterland and connects them to the upstream projects in neighbouring regions" has become very familiar to Asian nations. China's financial strategy includes FDI, aid, assistance and loans. Littoral nations invest in cooperation and partnerships as they are all trying to balance out their dependencies on one single power and diversify their partnerships.

Amid the strategic competition between the major powers, Bangladesh, Myanmar and Sri Lanka appear to have adopted an equidistant approach in managing their relationships with these actors. At the same time, the littorals are attempting to leverage their geostrategic location in the BoB by using the competition to their advantage and giving equal priority to their engagements with the major powers (Sakhuja 2010). In this context, the perceived spectre of India-China or China-US rivalry does not loom large. What gives the smaller littorals a bargaining chip is their significance and role in the realization of the major powers' larger strategic ambitions. To a certain extent, all the littorals can either facilitate connectivity and contribute to energy security or provide larger markets for trade to the major regional players. In return, these nations are benefiting from infrastructure development, financial assistance, integration, military modernization, etc. So far, the partnership between major powers and smaller littorals based on soft power has added stability to the security environment of the BoB.

\section{Militarization and the Changing Security Landscape}

All the talks of "rebalancing", securing SLOCs, attaining energy security, competition over scarce resources and the claims to sovereignty are potential drivers of conflict. In that regard, it is possible that the region might see a rapid militarization to protect and defend these interests. Policymakers in Beijing, Delhi, and Washington are aware of the idea that "the Indian Ocean and its adjacent waters will be a central theatre of global conflict and competition this century" (Kaplan 2010). If we look at the military developments of the past two decades in the region, one cannot deny the spiralling naval spending in the IOR and the SCS. Figure 7 shows Asian nations' military expenditure in the past 20 years. 


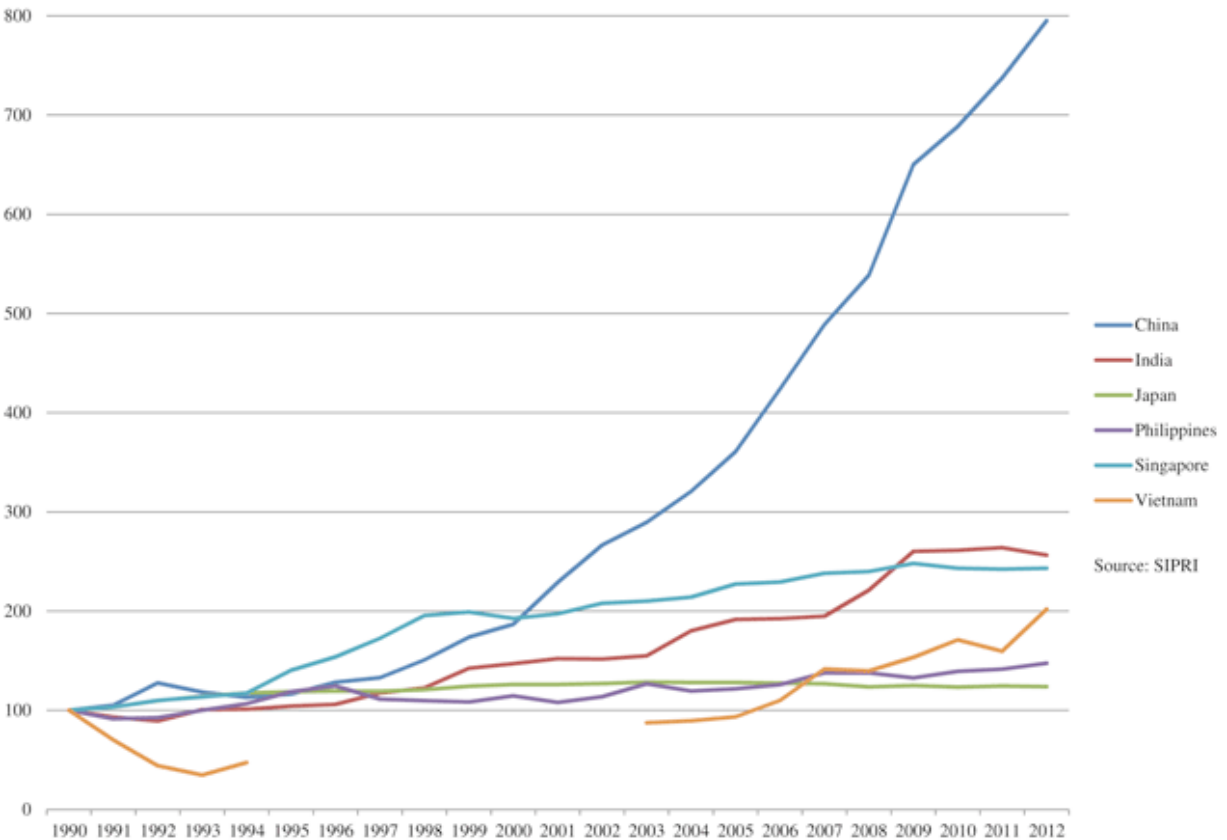

In the past few decades, a geopolitical shift has been emerging in the $\mathrm{BOB}$. The region has become a centre of attention for regional and extraregional powers, but none is considered to be the single most dominant maritime power.

Although the United States' maritime capabilities are still ahead of both China and India, the balance of power could change and foster ambitions for regional hegemony on the part of one of the two contenders (HCSS 2010). The US is by far the highest spender on overall defence and on maritime capabilities, allocating about $28 \%$ of its overall defence budget on maritime expenditures, amounting to a colossal USD 156 billion. China, on the other hand, dedicates $15 \%$ of its overall defence budget to its naval forces, amounting to USD 10.5 billion, while India allocates $7 \%$ of its overall defence expenditures for maritime power, amounting to a relatively modest amount of USD 2 billion (HCSS 2010). However, over the next decade, the defence budgets of China and India are projected to grow considerably. The maritime balance of power depends on the number and the nature of naval assets deployed in the region. Within the next two decades, the presence of assets in the Indian Ocean is expected to increase substantially (HCSS 2010). 
As India's Navy has evolved, it has shown ambition to project influence and power across the IOR and beyond (Stimson Report 2012). India has growing security relationships with all of its BOB neighbours and is keen to demonstrate its credentials in areas such as maritime policing, counter terrorism, and humanitarian disaster relief. It has participated significantly in relief operations, assisted in the aftermaths of major cyclones and has been involved in numerous counter-piracy operations (Stimson Report 2012). Delhi has been building its military power in the BoB, including new naval and air facilities in the Andaman and Nicobar Islands that run northsouth through the Bay, allowing it to potentially dominate the western end of the Malacca Strait and much of the surrounding waters (Brewster 2014). The Indian Navy is also gradually being 'rebalanced' towards the Bay through the expansion of its Eastern fleet with new carriers and nuclear submarines.

China is expanding its naval power projection capabilities well beyond its littoral, and indeed well beyond the SCS. Aside from alarming India and other Asian states, the rise in China's maritime power is also of concern to the US. The expansion of China's naval capabilities and broader military profile signifies its great-power status. The country's new naval strategy of "far sea defence" is aimed at giving Beijing the ability to project its power in key oceanic areas, most significantly in the Indian Ocean (Pant 2010). Moreover, China has been acquiring naval facilities along crucial choke-points in the IOR not only to serve its economic interests but also to enhance its strategic presence and protect energy imports (as it cannot rely on US naval power for unhindered access to energy) (Pant 2010).

The efforts of India and China to expand their influence in each other's backyards may result in regional conflicts, as is already apparent between the US and China in the South China Sea. The danger is that conflicts at sea could spill over to other areas of contention and also affect smaller littoral nations. For example, a war at sea between India and China could likely re-ignite the unresolved Sino-Indian border conflict as well (HCSS 2010). 


\section{Maintaining peace and stability in the Bay of Bengal}

\section{Challenges to Stability}

As shown above, the Bay region is vital to Asia's rising powers, but its low-lying littorals, home to over half a billion people, are vulnerable to a number of trans-boundary issues and threats.

At present, population growth, climate change, overexploitation of fisheries, degradation of critical habitats, pollution, and deteriorating water quality are reshaping the Bay. The pace and breadth of these challenges require regional cooperation that encourages the countries around the Bay to rise above their political fault-lines to work together. The Maldives, India, Sri Lanka, Bangladesh, Myanmar, Thailand, Indonesia and Malaysia are currently working together under the Bay of Bengal Large Marine Ecosystem (BOBLME) Project designed to improve the lives of the coastal populations through improved regional management of the Bay of Bengal environment and its fisheries. The project has been allocated a budget of US\$31 million for a period of 5 years (BOBLEM 2014).

The BoB's coasts are threatened by water conflicts in the Himalayas, and by the fracking of oil and gas in the deep sea. Dam construction in China and India poses a threat to downstream communities in India, Bangladesh and mainland Southeast Asia. The rising sea level, the subsiding of deltaic lands, and the accelerated intrusion of saltwater onto farmlands pose a severe threat to food production that would adversely affect millions. Climate change has exacerbated these impending consequences. Scientists have predicted a rise in the frequency and intensity of the Bay's deadly cyclones that in the past few years affected more than 18 million people in Bangladesh, Myanmar and Thailand. Yet on an optimistic note, the Bangladesh Cabinet approved the "National Oceanographic Research Institute Act" to establish a research institute within a maritime university to address the growing ecological and environmental concerns in the Bay of Bengal.

Another major challenge to stability comes from limited institutional 
capacities of the littoral nations, the majority of which we can qualify as "weak states". Internal political instability is one of the main obstacles to development, growth and cooperation. Most of the littoral nations of the Bay have been affected by it. Large amounts of investments went to Sri Lanka only after the civil war ended in 2009. Following the end of military rule, Myanmar is experiencing unprecedented FDI investment and is opening up to the western world because of the government's reforms. These examples help us understand the importance of political stability and its correlation to economic development, regional partnerships and overall prosperity.

Weak governance in particular near important choke points carries the risk of making these areas more vulnerable to piracy and terrorism.

It is, hence, in the best interest of not just regional, but also extra-regional powers to confront threats arising from piracy and terrorism at sea. The BoB urgently needs more effective cooperation for environmental protection and the mitigation of terrorist and piracy attacks on crucial sea routes - largely by the littoral countries as the most vulnerable. There remains a pressing need for more coordinated and comprehensive policies. Hope for a new regionalism lies in recognizing that the Bay's integrity, stability and ecology transcend national frontiers.

\section{Competition not Conflict}

There are certain potential sources of conflict in the BoB - geostrategic tension, growing energy demand leading to greater competition, and maritime relations, to name a few. The rise of China and India is affecting the international geopolitical landscape. As world history attests, the dramatic rise of a new power usually creates volatility in the international system (Chellany 2009).

The growing energy demand of the emerging powers will likely become a source of contention and competition. Additionally, since most of the major players in the Bay are investing in a military build-up, the nature of the confrontation might become more problematic. It is difficult to predict if and how these disputes will heat up but they are all potential sources of conflict and rivalry (HCSS 2010). 
Despite this somewhat bleak scenario, it seems that states have more incentive to cooperate than to confront each other. Over the last two decades, China and India have become increasingly economically interdependent. China's involvement in the development of BoB littorals leads to even greater interdependencies. These economic interests reduce the risks of conflict, forcing the countries to think more about their mutual benefits. Bilateral and multilateral trade agreements and the expanding memberships of regional organizations sUch as ASEAN, SAARC, the Indian Ocean Rim Association (IORA), or the BIMSTEC have a positive effect, particularly with regard to Sino-Indian relations. These institutions facilitate regional integration, mediate conflicts and promote healthy competition. Cooperation through an institutional body could assist the member countries in strengthening their external competitiveness. This could take the form of trade facilitation, infrastructure building, and technical assistance for complying with international standards.

Although it is often difficult to achieve in practice, the process of addressing common security challenges in the BoB (e.g., piracy and maritime terrorism) may also create a positive momentum on which to build a working relationship (HCSS 2010).

The ways in which the key powers will address mutual (and sometimes conflicting) maritime interests will directly affect the global balance of power and play a large role in determining the geopolitical landscape of the decades to come. The most significant ones involve changes in the balance of power and the risk of violent conflict and insecurity along the SLOCs, resulting in large-scale economic disruption and the rerouting of energy supply (HCSS 2010).

As a component of broader diplomatic relations, maritime relations between the major players in the BoB contribute to either confrontational or cooperative behaviours. Cooperation that addresses shared challenges as nuclear proliferation or international terrorism facilitates the establishment of working relationships. It may also have a trust-building dimension with potential spill over effects into the maritime realm (HCSS 2010). 


\section{The way forward and cooperation architecture}

The regional security architecture calls for active multilateralism. However, countries such as China rather engage bilaterally with the South Asian countries than through regional platforms (BCIM, BIMSTEC, etc.). Bilateralism in such a dynamic region is a double-edged sword on the one hand, bilateral projects are usually more flexible and faster to execute; on the other hand, bilateralism allows major powers to blunt unanimous opposition to their policies and keep the region divided.

It is becoming more evident that no single state will be able to dominate the region. Therefore, a multilateral setup will emerge to allow each country to pursue its goals on equal terms. For that to occur, it is necessary that countries give more credibility to multilateral arrangements. In view of the circumstances and geo-political realities, the US will have to change its position from dominance to partnership with the regional powers. It may, in the future, act as a 'balancer' between China and India.

The geopolitical landscape of the BoB will evolve in different ways over the next decades. It will mainly depend upon the level and nature of the maritime build-up and the level of cooperative or confrontational relations between the powers. Because of the extraordinary growth rates recorded by the economies of China, India, and other countries in southern Asia, experts are predicting that the world's economic centre of gravity will gradually shift to the East. This is largely a result of the particular economic policies of these countries, oriented toward export-led growth. At the same time, these countries are also heavily dependent on imports, especially the Chinese and Indian economies, in order to meet the expanding energy needs of their growing industries and populations.

In the future, there may be more stability since many littoral states are moving towards a democratic system that will create more investor confidence. Superpowers may also rely on soft rather than hard power in their competition. As for the US, Kaplan predicts a waning in their presence as an "elegant decline from hegemony by fostering cooperation with other navies to protect the maritime commons. The more China and India 
rise, the more welcome US power will be in the region as a counterbalance to both" (Kaplan 2010).

The BoB will require close attention in the coming years. As the Bay will become a playground in a nascent multi-polar world order, it is of the utmost importance to establish governance frameworks that will facilitate the integration of rising powers in regulating this order and upholding the principles of an open world economy (Kaplan 2010). 


\section{Bibliograph}

Agnihotri, K. K., 2014. China and US in the Indian Ocean. Institute of Peace and Conflict Studies (IPSC). \#4475.

Amrith, S. S., 2013. Crossing the Bay of Bengal. New York: Harvard University Press.

Asia News Network, 2013. Myanmar expects more Japanese investments in manufacturing, IT. [online] July 31 2013. Available at: http://www. asianewsnet.net/Myanmar-expects-more-Japanese-investmentsin-manuf-49683.html [accessed July 2013].

BBC News Asia, 2014. US announces Burma sanctions move. [online] Available at: http://www.bbc.com/news/world-asia-22393696 [accessed November 2014]

Bedford, C., 2009. The View from the West: Chinese Naval Power in the 21 st Century. Canadian Naval Review, Vol 5, N² 2, Summer 2009.

Bhadrakumar, M., 2013. The Great Game syndromes in Bay of Bengal. Strategic Culture Foundation. [online] January 25 2013. Available at: http://www.strategic-culture.org/news/2013/01/25/the-greatgame-syndromes-in-bay-of-bengal.html [accessed July 2014].

Bhatnagar, G. V., 2013. First India-Japan maritime exercise in Bay of Bengal. The Hindu. [online] December 17, 2013. Available at: http://www. thehindu.com/news/national/first-indiajapan-maritime-exercise-inbay-of-bengal/article5469941.ece [accessed July 2014].

The Bay of Bengal Large Marine Ecosystem Project (BOBLME) Website, 2014. [online] Available at: http://www.boblme.org/project_ overview.html [accessed August 2014].

Brewster, D., 2014. The Bay of Bengal: A New Locus for Strategic Competition in Asia. East-West Center: Asia Pacific Bulletin, Number 263 | May 15, 2014.

British Petroleum, 2011. Statistical Review of World Energy. [online]. Available at: http://www.bp.com/content/dam/bp-country/ 
de_de/PDFs/brochures/statistical_review_of_world_energy_full_ report_2011.pdf [accessed July 2014].

Burke, N., 2014. Annex VIl Arbitral Tribunal Delimits Maritime Boundary Between Bangladesh and India in the Bay of Bengal. Volume: 18, Issue 20. September 22.

Center for a New American Security, 2009. China's Arrival: A Strategic Framework for a Global Relationship.

Chellany, B., 2014. China's economic miracle needs political modernisation to sustain it. The Economic Times. [online] Available at: http://articles. economictimes.indiatimes.com/2009-12-20/news/27648281_1_ china-chinese-foreign-policy-biggest-trade-surplus [accessed July 2014].

Chintamani, M., 2014. US' Frantic Effort to Make the Rebalancing Strategy Work. Institute of Peace and Conflict Studies (IPSC). \#4430, 12 May 2014.

Columbage, D., 2014. Sri Lanka's surging cash reliance on China. Al Jazeera [online] August 16, 2014. Available at: http://www.aljazeera.com/ indepth/features/2014/08/sri-lanka-economy-reliance-china-infras tructure-20148256345589851.html [accessed November 2014]

Cordesman, A. H., Toukan, A., 2014. The Indian Ocean Region: A Strategic Net Assessment. Center for Strategic and International Studies (CSIS). [online] April 1 2014. Available at: http://csis.org/files/ publication/IOR\%20Net\%20Assessment\%201\%20APRIL\%202014\%20 (reduced\%20size).pdf [accessed July 2014].

The Economist, 2013. New bay dawning. [online] April 272013. Available at: http://www.economist.com/news/asia/21576721harbours-eastern-lobe-indian-ocean-could-transform-economicgeography-asia-new\#sthash.upzzpfWe.dpuf [accessed June 2014].

Encyclopaedia Britannica, 2009. [online] Available at: http://www. britannica.com/EBchecked/topic/60740/Bay-of-Bengal [accessed December 2014].

Eshel, D., 2011 . Flashpoints: Asia, 'String Of Pearls' Is Securing China's 
Sea Lanes. Defence Update. [online] Available at: http://www. defense-update.com/analysis/2010/20122010_analysis_string_of_ pearls.html [accessed June 2014].

The Daily Star, 2014. Japan pledges $\$ 5$.9b. [online] May 27, 2014. Available at: $\quad$ http://www.thedailystar.net/japan-pledges-5-9b-25828 [accessed June 2014].

The Daily Star, 2014. Xi calls for stronger frontier defences. [online] June 29, 2014. Available at: http://www.thedailystar.net/newsarchive/xicalls-for-stronger-frontier-defences-30815 [accessed July 2014].

Devare, S. T., 2008. A New Energy Frontier: The Bay of Bengal Region. Singapore: ISEAS Publishing.

Goldman Sachs, 2007. Beyond the BRICs: a look at the next 11. [online]. Available at: http://www.goldmansachs.com/our-thinking/ archive/archive-pdfs/brics-book/brics-chap-13.pdf [accessed July 2014].

Goodman, J., 2014. Sri Lanka's Growing Links with China. The Diplomat.

Government of India Ministry of External Affairs, 2014. India Sir Lanka Relations. [online] January 2014. Available at: http://www.mea.gov. in/Portal/ForeignRelation/Sri_Lanka_January_2014.pdf [accessed July 2014].

The Hague Centre for Strategic Studies, 2010. The Maritime Future of the Indian Ocean. Future Issue $\mathrm{No}^{\circ} 13$ | 09 | 10

Hughes, L., 2014. Examining the Sino-Indian Maritime Competition: Part 4 - India's Maritime Strategy. Future Directions International. [online] January 30 2014. Available at: http://www.futuredirections.org. au/publications/indian-ocean/1516-examining-the-sino-indianmaritime-competition-part-4-india-s-maritime-strategy.html [accessed July 2014].

Jha, G. K., 2014. Rebalancing: China's Concerns and Responses. Institute of Peace and Conflict Studies. Article $n^{\circ} \# 4438$.

Jia, C., 2014. China studying new Silk Road rail link to Pakistan. China daily US Edition. [online] Available at: http://usa.chinadaily.com.cn/ business/2014-06/28/content_17621848.htm [accessed on July 2014]. 
Kabir, H., 2014. China team to discuss \$9.0b loan issues in Dhaka today. The Financial Express. [online] September 22 2014. Available at: http:// www.thefinancialexpress-bd.com/2014/09/22/57529 [accessed November 2014].

Kaplan, R. D., 2010. Monsoon: The Indian Ocean and the Future of American Power. New York: Random House Publishing.

Kapur, P., 2014. China and US in the Indian Ocean. Institute of Peace and Conflict Studies (IPSC). \#4475, 30 May 2014.

Keck, Z., 2014. How South Asia Resolves Maritime Disputes. The Diplomat [online] July 10, 2014. Available at: http://thediplomat.com/2014/07/how-southasia-resolves-maritime-disputes/ [accessed November 2014].

Khan, A. ur R., 2013. Evolving Geopolitics of Indian Ocean: In-depth Analysis. ORIENTAL REVIEW Open Research and Discussion Journal, August 62013.

McDevitt, M. A., 2013. The Long Littoral Project: Summary Report. A Maritime Perspective on Indo-Pacific Security. Center for Naval Analysis (CAN): Strategic Studies Division Report.

Melkulangara, B., 2014. The Great Game syndromes in Bay of Bengal. Strategic Culture Foundation. [online] January 25 2013. Available at: http://www.strategic-culture.org/news/2013/01/25/the-greatgame-syndromes-in-bay-of-bengal.html [accessed July 2014].

Pant, H. V., 2010. China's Naval Expansion in the Indian Ocean and IndiaChina Rivalry. The Asia-Pacific Journal: JapanFocus, May 2010.

Rajan, D. S., 2014. The Unfolding China's Indian Ocean Strategy. South Asia Analysis Group, Paper No. 5646.

Ramaswamy, S., Maini, T. S., 2014. The Strategic Importance of Myanmar for India. The Diplomat. [online] August 12 2014. Available at: http:// thediplomat.com/2014/08/the-strategic-importance-of-myanmarfor-india/ [accessed August 2014].

Samaranayake, N., 2014. The Indian Ocean: A Great-Power Danger Zone? The National Interest. May 302014.

Sakhuja, V., 2010. Bay of Bengal Littorals in Chinese Strategic Calculus. The 
Jamestown Foundation. China Brief Volume: 10, Issue: 14. July 2010.

Song, S., 2013. Myanmar's Economy To Receive Boost From Japanese And Korean Investment. The International Business Times. [online] June 21 2013. Available at: http://www.ibtimes.com/myanmarseconomy-receive-boost-japanese-korean-investment-1318389 [accessed July 2014].

Shannon, 2014. China Offers $\$ 20$ Billion in Loans to ASEAN. The Diplomat [online] November 15 2014. Available at: http://thediplomat. com/2014/11/china-offers-20-billion-in-loans-to-asean/ [accessed November 2014].

Stimson Report, 2012. Indian Ocean Rising: Maritime Security and Policy Challenges.

Strat Risks. 2013. Observing the Grand Geopolitical Game of Risk. Evolving strategic competition in the Indian Ocean. [online] April 18, 2013. Available at: http://stratrisks.com/geostrat/11940 [accessed July 2014].

Szczepanski, K., 2014. Indian Ocean Trade Routes. Asian History [online]. Available at: http://asianhistory.about.com/od/ indiansubcontinent/ss/Indian-Ocean-Trade-Routes.htm [accessed December 2014].

The Times of India, 2014. China wants India in Silk Road plan. [online] August 11 2014. Available at: http://timesofindia.indiatimes.com/world/ china/China-wants-India-in-silk-road-plan/articleshow/40031084. cms [accessed August 2014].

Vines, A., 2012. Mesmerised by Chinese string of pearls theory. The World Today | February \& March | 2012.

Yhome, K., 2014. Myanmar and the geopolitics of the Bay of Bengal. ORF Issue Brief, Number 68.

Yoon, S., 2014. Xi Jinping's 'Monroe Doctrine': Rebuilding the Middle Kingdom Order? S. Rajaratnam School of International Studies (RSIS), Issue 102. 2014. 
Mohammad Humayun Kabir (hkabir@bei-bd.org) is Senior Research Director at the Bangladesh Enterprise Institute in Dhaka, Bangladesh, and head of its Foreign Policy and Security Studies Division. He studied International Law in Kiev State University, Ukraine, and International Relations at Oxford University, UK. He is a recipient of several awards such as the Commonwealth Scholarship (at Oxford, UK), the Ford Foundation Fellowship (in India, Sri Lanka and Singapore) and the Senior Fulbright Scholarship (at Boston, USA). He has conducted research in India, Sri Lanka, Singapore, the UK and the USA. His areas of research interests are foreign policy, national/regional/international security, UN peacekeeping, international political and security trends, security sector development, civil-military relations, non-traditional security, human security, violent extremism/terrorism, governance issues, water issues, inter-state relations in South Asia, etc. With thirty three years of experience in research and academic administration, he has to his credit about sixty research works, as well as many unpublished research works.

Amamah Ahmad (amama.ahmad@gmail.com) is a Research Associate at the Bangladesh Enterprise Institute in Dhaka, Bangladesh. She graduated with a Bachelor of Arts in Social Science and a Master of Arts in Political Science from the University of Lausanne in Switzerland. She has research interests in Geopolitics, International Security and Transboundary issues. 